\title{
Perbedaan Status Gizi dan Penyakit Infeksi pada Anak Baduta yang Diberi ASI Eksklusif dan Non ASI Eksklusif
}

\section{The Differences of Nutritional Status and Infection Disease in Exclusive Breastfeed and Non Exclusive Breastfeed Toddlers}

\author{
Lury Novita Yustianingrum ${ }^{* 1}$, Merryana Adriani $^{1}$
}

\begin{abstract}
ABSTRAK
Latar belakang: Cakupan ASI eksklusif di Jawa Timur belum mencapai target dan mengalami penurunan pada tahun 2015. Ibu yang bekerja dan kegagalan pelaksanaan IMD merupakan faktor yang dapat menghambat pemberian ASI eksklusif. Pemberian non ASI eksklusif pada bayi akan meningkatkan risiko malnutrisi dan kejadian penyakit infeksi.

Tujuan: Tujuan dari penelitian ini adalah untuk menganalisa perbedaan status gizi dan kejadin penyakit infeksi pada anak baduta ASI esklusif dan non ASI eksklusif usia 12-24 bulan di Desa Randegan, Tanggulangin, Sidoarjo.

Metode: Penelitian ini merupakan penelitian observasional dengan menggunakan desain cross sectional. Sampel terdiri dari 44 anak baduta di Desa Randegan Kecamatan Tanggulangin Kabupaten Sidoarjo. Dimana terdiri dari anak baduta ASI eksklusif dan non ASI eksklusif masing-masing berjumlah 22 anak baduta. Pengumpulan data menggunakan kuesioner dan penimbangan berat badan. Data dianalisis menggunakan chi square.

Hasil: Status gizi baik anak baduta ASI eksklusif yaitu 95,5\% dan non ASI eksklusif yaitu 59,1\%. Kejadian penyakit infeksi pada anak baduta ASI eksklusif yaitu $27,3 \%$ dan non ASI eksklusif yaitu $81,8 \%$. Hasil dari penelitian pada kedua kelompok menunjukkan ada perbedaan signifikan $(p<0,05)$ pada status gizi dan kejadian penyakit infeksi.

Kesimpulan: Anak baduta ASI eksklusif memiliki status gizi baik yang lebih tinggi dan kejadian penyakit infeksi yang lebih rendah dari pada anak baduta non ASI eksklusif. Ibu anak baduta harus lebih memperhatikan higieni sanitasi lingkungan dan memberikan asupan makanan yang bergizi serta berimbang.
\end{abstract}

Kata kunci: ASI eksklusif, status gizi, penyakit infeksi 


\section{ABSTRACT}

Background: The coverage of exclusive breastfeed in East Java has not reached the target has decreased in 2015. Working mother and the failed breast crawl implementation is factor that can inhibit exclusive breastfeed. Non exclusive breastfeed in infant will increase the risk of malnutrition and infectious disease.

Objectives: The purpose of this study is to analyze the difference of nutritional status and infectious disease in exclusive breastfeed dan non exclusive breastfeed toodler age 12-24 months in Randegan village, Tanggulangin, Sidoarjo.

Methods: The research was an observational analytic with cross sectional design. The sampel of this study was 44 toddlers in Randegan Village, Tanggulangin, Sidoarjo. Consists of 22 each exclusive breastfeed dan non breastfeed toddlers. The data were collected by questionnaires and weight measurement. Data were analyzed using chi square.

Result: Normal nutritional status of exclusive breastfeed toddlers was $95.5 \%$ and of non exclusive breastfeed was 59.1\%. The incidence of infection disease of exclusive breastfeed was $27.3 \%$ and of non exclusive breastfeed was $81.8 \%$. The result of this study in both group showed of exclusive breastfeed and non exclusive breastfeed toodlers were significant $(p<0.05)$ in nutritional status and incidence of infectious disease.

Conclusion: Exclusive breastfeed toodlers has a better nutritional status and lower incedence of infectious disease than non exclusive breastfeed toddlers. Mother of toddlers should pay more attention to monitoring of growth and development in children, hygiene and sanitation, and giving nutritious and balanced food intake.

Keywords: breastfeed, nutritional status, infectious disease

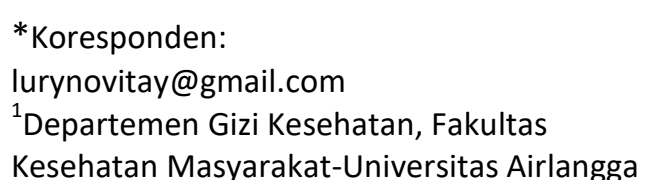

\section{PENDAHULUAN}

Tercukupinya kebutuhan gizi anak akan tergambar salah satunya dari status gizi. Kecukupan pemenuhan kebutuhan gizi anak yang tidak adekuat akan berpengaruh pada terjadinya gizi kurang ${ }^{1}$. Jawa Timur merupakan provinsi yang masih dapat ditemukan balita dengan kejadian malnutrisi. Presentase status gizi balita berdasarkan BB/U di Jawa Timur yaitu gizi buruk sebesar 2,0\% dan gizi kurang sebesar 10,3 ${ }^{2}$. Presentase status gizi balita berdasarkan indikator BB/ $\mathrm{U}$ tahun 2016 di Kabupaten Sidoarjo yaitu angka gizi buruk sebesar $1,6 \%$, gizi kurang sebesar $14,9 \%$, dan gizi baik sebesar $83 \%$ dan gizi lebih sebesar $0,5 \%$. Kejadian gizi buruk dan gizi kurang di Kabupaten Sidoarjo beberapa diantaranya dipengaruhi oleh asupan makanan anak dan kejadian penyakit infeksi ${ }^{3}$.
Kejadian penyakit infeksi pada anak akan mempengaruhi pada penurunan nafsu makan anak yang merupakan suatu gejala klinis suatu penyakit, sehingga asupan makanan anak akan berkurang. Apabila keadaan penurunan asupan makan terjadi dalam waktu yang cukup lama disertai dengan kondisi muntah dan diare maka anak juga akan mengalami kehilangan zat gizi dan cairan. Dimana kondisi ini akan berdampak pada penurunan berat badan anak, sehingga perubahan status gizi anak yang semula sebelum mengalami penyakit infeksi memiliki status gizi baik, menjadi status gizi kurang, bahkan apabila kondisi tersebut tidak termanajemen dengan baik anak akan mengalami gizi buruk ${ }^{4}$. Kejadian penyakit infeksi seperti pneumonia pada 38 kota/Kabupaten di Jawa Timur, hanya terdapat 1 kota/kabupaten yang telah 
memenuhi target cakupan balita pneumonia. Berdasarkan data jumlah balita yang menderita penyakit infeksi seperti pneumonia di Kabupaten Sidoarjo pada tahun 2015 sebesar 8.834 dan jumlah ini peningkatan dari tahun 2014, dimana penyebabnya seperti asupan makanan anak, higieni sanitasi lingkungan dan, kelengkapan imunisasi dasar ${ }^{3}$.

Pemberian asupan makanan yang tepat dan sesuai dengan kebutuhan gizi anak mampu mencegah terjadinya kejadian malnutrisi dan retardasi, namun sebaliknya ketidaktepatan dan ketidaksesuaian pemberian asupan makanan anak akan dapat meningkatkan risiko kejadian penyakit infeksi dan kematian ${ }^{5}$. Pemberian asupan makanan yang dapat mempengaruhi status gizi dan kejadian penyakit infeksi pada anak yaitu salah satunya asupan ASI eksklusif pada masa awal kehidupan. ASI eksklusif adalah pemberian asupan makanan kepada bayi hingga berusia 6 bulan dengan ASI saja, tanpa ditambahkan cairan yang lainnya seperti susu formula, air putih, air jeruk, atau jenis makanan tambahan lainnya ${ }^{6}$. Bayi selama berusia 0 sampai 6 bulan kebutuhan gizinya cukup dipenuhi oleh pemberian ASI eksklusif, maka dari itu bayi yang tidak diberikan ASI eksklusif pemenuhan kebutuhan gizinya tidak optimal. Kemudian ketika anak mulai menginjak usia 6 bulan, kebutuhan gizinya mampu tercukupi dari pemberian ASI dan Makanan Pendamping ASI (MP ASI). Penelitian sebelumnya mendukung pernyataan bahwa asupan makanan seperti pemberian ASI eksklusif akan mempengaruhi status gizi anak, dimana pada penelitian tersebut menyatakan bahwa bayi ASI eksklusif $100 \%$ memiliki status gizi baik, sedangkan bayi non ASI eksklusif $58,80 \%$ memiliki status gizi baik ${ }^{4}$.

ASI eksklusif yang tidak diberikan secara optimal selama 6 bulan akan berdampak pula pada 30\% kematian balita akibat diare dan $18 \%$ akibat infeksi saluran pernafasan ${ }^{7}$. ASI mengandung berbagai jenis zat gizi yang memiliki fungsi sebagai protektif untuk daya tahan tubuh anak sejak bayi ${ }^{8}$. Immunoglobulin $A(\lg A)$ merupakan zat protektif yang terkandung dalam ASI berfungsi untuk melindungi saluran pencernaan bayi dari bakteri penyebab infeksi ${ }^{5}$. Pada penelitian sebelumnya menyebutkan bahwa terdapat perbedaan yang signifikan kejadian diare pada kelompok bayi ASI eksklusif dan susu formula yang ditunjukkan pada frekuensi kejadian diare. Dimana bayi yang diberi ASI eksklusif menderita diare yang jarang, sedangkan pada bayi dengan susu formula sering mengalami diare $^{9}$

Apabila dilihat cakupan ASI eksklusif di Indonesia pada tahun 2015 sebesar 55,7\% dimana angka tersebut masih belum mencapai target yang ditentukan ${ }^{10}$. Apabila melihat angka cakupan ASI eksklusif di Jawa Timur menunjukkan adanya penurunan dan belum mencapai target yaitu sebesar $80 \%$. Cakupan ASI eksklusif di Jawa Timur pada tahun 2014 sebesar 72,89\%, kemudian mengalami penurunan pada tahun 2015 menjadi sebesesar $68,8 \%^{2}$.

Menurut Dinas Kesehatan Kabupaten Sidoarjo (2016), cakupan ASI eksklusif di Kabupaten Sidoarjo pada tahun 2015 belum mencapai target yaitu sebesar $57,30 \%$. Dinas Kesehatan Kabupaten Sidoarjo memiliki 26 Puskesmas yang tersebar di beberapa kecamatan. Salah satu Puskesmas di Kabupaten Sidoarjo yang mana cakupan ASI eksklusif dalam wilayah kerjanya belum mencapai target yaitu Puskesmas Tanggulangin. Cakupan ASI eksklusif di Puskesmas Tanggulangin pada tahun 2015 yaitu sebesar $49,6 \%^{3}$. Kabupaten sidoarjo merupakan salah satu daerah yang telah melaksanakan beberapa program untuk peningkatan cakupan ASI eksklusif. Program yang telah dilaksanakan hingga tahun 2016 yaitu Kelompok Pendukung ASI (KP-ASI), pelatihan konselor menyusui, pojok laktasi untuk setiap perusahaan dengan pekerja wanita, dan Pemberian Makanan Bagi Anak (PMBA) $)^{3}$.

Terdapat beberapa faktor yang dapat menghambat keberhasilan pemberian ASI eksklusif pada bayi seperti pengetahuan ibu yang kurang dalam hal ASI eksklusif, sebagian dari ibu yang bekerja memutuskan cara yang lebih praktis dengan mengganti ASI atau memberikan tambahan susu formula, dan tidak dilaksanakannya Inisiasi Menyusi Dini (IMD) sesaat setalah ibu melahirkan ${ }^{11}$. Berdasarkan uraian di atas, maka perlu diadakannya penelitian untuk melihat 
perbedaan status gizi dan penyakit infeksi pada anak baduta yang diberi ASI eksklusif dan non ASI eksklusif.

\section{METODE}

Penelitian dilaksanakan pada bulan Juli tahun 2017 di Desa Randegan wilayah kerja Puskesmas Tanggulangin Sidoarjo. Penelitian ini dilaksanakan dengan menggunakan metode observasional analitik dengan menggunakan desain cross sectional. Populasi dalam penelitian ini adalah seluruh anak baduta usia 12-24 bulan yang diberi ASI eksklusif dan non ASI eksklusif yang berjumlah 77 anak baduta. Besar sampel yang diperlukan dalam penelitian ini berdasarkan perhitungan menggunakan rumus uji hipotesis untuk dua proporsi populasi yaitu 22 anak baduta pada masing-masing kelompok. Pemilihan sampel pada setiap kelompok diambil menggunakan simple random sampling.

Variabel terikat dalam penelitian ini adalah status gizi dan penyakit infeksi pada anak baduta, sedangkan variabel bebasnya adalah riwayat pemberian ASI eksklusif. Karakteristik anak baduta dan ibu anak baduta yang digunakan untuk mendukung penelitian ini adalah jenis kelamin anak baduta, berat badan lahir, tingkat pendidikan ibu dan status pekerjaan. Jenis data yang dipergunakan dalam penelitian ini adalah data primer dan data sekunder. Data primer meliputi penimbangan berat badan menggunakan timbangan digital merek Kris Chef dengan ketelitian 0,1 kg, penilaian kejadian penyakit infeksi pada 1 bulan terakhir dan karakteristik anak baduta serta ibu. Sedangkan untuk data sekunder adalah riwayat pemberian ASI pada anak baduta yang didapatkan dari Posyandu di Desa Randegan. Penilaian status gizi dalam penelitian ini menggunakan indikator $\mathrm{BB} / \mathrm{U}$.

Penelitian ini menggunakan analisis univariat dan bivariat. Analisis univariat untuk melihat distribusi variabel yang diteliti dan karakteristik anak baduta serta ibu pada dua kelompok anak baduta ASI eksklusif dan non ASI eksklusif. Analisis bivariat digunakan untuk melihat perbedaan status gizi dan kejadian penyakit infeksi pada kelompok anak baduta ASI eksklusif dan non ASI eksklusif dengan menggunakan uji chi square fisher exact test.

\section{HASIL DAN PEMBAHASAN}

Karakteristik anak baduta dan ibu pada tabel 1 menunjukkan bahwa pada kelompok anak baduta ASI eksklusif dan non ASI eksklusif jenis kelamin terbanyak masingmasing perempuan yakni 12 anak baduta $(54,5 \%)$ dan 14 anak baduta $(63,6 \%)$. Hasil ini sejalan dengan penelitian sebelumnya yang menyatakan bahwa sebagian besar bayi yang mendapatkan ASI eksklusif ialah berjenis kelamin perempuan yakni $58,82 \%{ }^{12}$. Namun hasil tersebut yang bertentangan dengan penelitian sebelumnya yang menyatakan bahwa bayi yang mendapatkan ASI eksklusif paling banyak berjenis kelamin laki-laki yakni $54,1 \%{ }^{13}$. Pemberian jumlah ASI bagi anak tergantung pada kebutuhan gizi anak, namun kebutuhan gizi anak tidak akan sama setiap individu. Kebutuhan gizi anak akan sangat bergantung akan faktor yang mempengaruhi seperti tingkat keaktifan anak yang dapat dilihat dari aktivitas anak dan metabolisme tubuh anak ${ }^{4}$.

Pada kelompok anak baduta dengan berat badan lahir rendah sebagian besar memiliki riwayat ASI eksklusif yakni 3 anak baduta (13,6\%). Hasil tersebut sejalan dengan penelitian sebelumnya yang dilakukan pada anak usia 3-4 tahun di Kecamatan Banyumanik Kota Semarang yang menyatakan bahwa pada kelompok anak yang lahir dengan berat badan lahir rendah paling banyak memiliki riayat pemberian ASI eksklusif yakni $11,9 \%{ }^{14}$. ASI merupakan satu-satunya makanan terbaik bagi bayi yang lahir dengan berat badan lahir rendah ${ }^{15}$. Anak yang lahir dengan berat badan lahir rendah atau prematur tetap memiliki kemampuan yang sama dengan anak yang lahir dengan berat badan lahir normal dalam hal kemampuan menyusui pada ibunya. Namun kemampuan menyusuinya masih belum kuat, seiring dengan bertambahnya usia anak dan penambahan berat badannya, kemampuan anak untuk menyusui kepada ibunya akan semakin kuat ${ }^{16}$. Apabila anak kemampuan menyusunya masih sangat lemah atau pemberian ASI langsung pada bayi kecil dalam beberapa minggu tidak memungkinkan, maka pemberian ASI dapat dilakukan dengan ibu memerah ASI dan dibantu dengan 
menggunakan cangkir ketika memberikannya kepada anak. ASI merupakan satu-satunya makanan terbaik bagi bayi dengan berat badan lahir rendah ${ }^{15}$.

Pendidikan ibu pada kedua kelompok anak baduta paling banyak ialah pendidikan menengah (SMA/SMK/Sederajat) yakni $10 \mathrm{ibu}$ anak baduta ASI eksklusif (45,5\%) dan 15 ibu anak baduta non ASI eksklusif (68,2\%). Hasil ini sejalan dengan penelitian sebelumnya yang menyatakan bahwa sebagian besar ibu bayi yang memberikan ASI eksklusif berpendidikan tamat SMA yakni $27,8 \%{ }^{17}$.

Tabel 1. Distibusi Karakteristik Anak Baduta dan Ibu pada Anak Baduta ASI Eksklusif dan Non ASI Eksklusif di Desa Randegan tahun 2017

\begin{tabular}{|c|c|c|c|c|}
\hline \multirow{3}{*}{ Karakteristik } & \multicolumn{4}{|c|}{ Riwayat Pemberian ASI } \\
\hline & \multicolumn{2}{|c|}{ ASI Eksklusif } & \multicolumn{2}{|c|}{ Non ASI eksklusif } \\
\hline & $\mathrm{n}$ & $\%$ & $\mathbf{n}$ & $\%$ \\
\hline \multicolumn{5}{|l|}{ Jenis Kelamin Anak Baduta } \\
\hline Laki-laki & 10 & 45,5 & 8 & 36,4 \\
\hline Perempuan & 12 & 54,5 & 14 & 63,6 \\
\hline Total & 22 & 100,0 & 22 & 100,0 \\
\hline \multicolumn{5}{|l|}{ Berat Badan Lahir Anak Baduta } \\
\hline Berat Badan Lahir Rendah (<2500 gram) & 3 & 13,6 & 2 & 9,1 \\
\hline Berat Badan Lahir Normal ( $\geq 2500$ gram) & 19 & 86,4 & 20 & 90,9 \\
\hline Total & 22 & 100,0 & 22 & 100,0 \\
\hline \multicolumn{5}{|l|}{ Tingkat Pendidikan Ibu } \\
\hline Rendah (SD/SMP/Sederajat) & 7 & 31,8 & 5 & 22,7 \\
\hline Menengah (SMA/SMK/Sederajat) & 10 & 45,5 & 15 & 68,2 \\
\hline Tinggi (minimal D1) & 5 & 22,7 & 2 & 9,1 \\
\hline Total & 22 & 100,0 & 22 & 100,0 \\
\hline \multicolumn{5}{|l|}{ Status Pekerjaan Ibu } \\
\hline Bekerja & 6 & 27,3 & 7 & 31,8 \\
\hline Tidak Bekerja & 16 & 72,7 & 15 & 68,2 \\
\hline Total & 22 & 100,0 & 22 & 100,0 \\
\hline
\end{tabular}

Tabel 2. Perbedaan Status Gizi pada Anak Baduta ASI eksklusif dan Non ASI Eksklusif di Desa Randegan Tahun 2017

\begin{tabular}{lccccc}
\hline & \multicolumn{4}{c}{ Riwayat Pemberian ASI } & \multirow{2}{*}{ Status Gizi Anak Baduta } \\
\cline { 2 - 5 } & \multicolumn{3}{c}{ ASI Eksklusif } & Non ASI eksklusif & \multirow{2}{*}{$\boldsymbol{p}$} \\
\cline { 2 - 5 } & $\mathbf{n}$ & $\boldsymbol{\%}$ & $\mathbf{n}$ & $\boldsymbol{\%}$ & \\
\hline Gizi Kurang & 1 & 4,5 & 9 & 40,9 & \\
Gizi Baik & 21 & 95,5 & 13 & 59,1 & \multirow{2}{*}{0,009} \\
\hline Total & 22 & 100,0 & 22 & 100,0 & \\
\hline
\end{tabular}


Tabel 3. Perbedaan Kejadian Penyakit Infeksi pada Anak Baduta ASI eksklusif dan Non ASI Eksklusif di Desa Randegan Tahun 2017

\begin{tabular}{lccccc}
\hline & \multicolumn{4}{c}{ Riwayat Pemberian ASI } & \multirow{2}{*}{ Kejadian Penyakit Infeksi Anak Baduta } \\
\cline { 2 - 5 } & \multicolumn{2}{c}{ ASI Eksklusif } & Non ASI & eksklusif & \multirow{2}{*}{ Nilai $\boldsymbol{p}$} \\
\cline { 2 - 5 } & $\mathbf{n}$ & $\%$ & $\mathbf{n}$ & $\%$ & \\
\hline Sakit & 6 & 27,3 & 18 & 81,8 & \\
Tidak Sakit & 16 & 72,7 & 4 & 18,2 & \multirow{2}{*}{0,001} \\
\hline Total & 22 & 100,0 & 22 & 100,0 & \\
\hline
\end{tabular}

Penelitian lain yang bertolak belakang dengan hasil penelitian ini menyatakan bahwa sebagian besar pendidikan ibu anak yang memiliki riwayat pemberian ASI eksklusif atau tidak sebagian besar berpendidikan tinggi yaitu Diploma/Sarjana ${ }^{18}$. Perilaku menyusui seorang ibu salah satunya dipengaruhi oleh pendidikan yang diterimanya. Pendidikan merupakan sebuah media ibu dapat mengakses informasi dan pengetahuan terkait dengan pola asuh. Orang tua memegang peranan yang utama dalam penentuan pola asuh yang diberikan kepada anak sejak kecil. Polah asuh yang kurang tepat tentunya akan mempengaruhi pola pemberian makanan kepada anak dan berdampak pada masalah kesehatan anak ${ }^{19}$.

Status pekerjaan ibu sebagian besar tidak bekerja yakni 16 ibu anak baduta ASI eksklusif $(72,2 \%)$ dan 15 ibu anak baduta non ASI eksklusif $(68,2 \%)$. Hasil penelitian ini sejalan dengan penelitian sebelumnya yang menyatakan bahwa sebagian besar pekerjaan ibu yang memberikan ASI eksklusif pada bayinya adalah ibu rumah tangga yakni $82,36 \%{ }^{4}$. Ibu yang bekerja memiliki risiko 4 kali lebih besar untuk menghentikan pemberian ASI eksklusif jika dibandingkan dengan ibu yang tidak bekerja ${ }^{20}$. Apabila dilihat dari segi waktu, ibu yang tidak bekerja memiliki banyak waktu untuk memberikan ASI eksklusif kepada anaknya. Namun pada hakikatnya keberhasilan dalam pemberian ASI eksklusif tidak terletak pada seberapa besar waktu luang ibu, tetapi dari kemauan ibu untuk memberikan pola asuh yang sesuai dan dorongan dari keluarga ${ }^{21}$. Ibu yang memiliki tekad tinggi untuk memberikan ASI eksklusif pada anak akan mempersiapkan diri sejak awal dengan informasi mengenai manajemen laktasi dan mengaplikasikannya.
Berdasarkan hasil tabulasi silang pada tabel 2 menunjukkan bahwa status gizi berdasarkan indikator $\mathrm{BB} / \mathrm{U}$ pada kedua kelompok anak baduta sebagian besar dalam kategori status gizi baik yakni 21 anak baduta ASI eksklusif (95,5\%) dan 13 anak baduta non ASI eksklusif $(59,1 \%)$. Sedangkan anak baduta dengan status gizi kurang berdasarkan BB/U yakni 1 anak baduta ASI eksklusif (4,5\%) dan 9 anak baduta non ASI eksklusif (40,9\%). Hasil tersebut sesuai dengan penelitian sebelumnya yang menyatakan bahwa bayi yang diberi ASI eksklusif sebagian besar memiliki status gizi baik berdasarkan $\mathrm{BB} / \mathrm{U}^{4}$.

Berdasarkan uji statistik didapatkan hasil bahwa terdapat perbedaan yang signifikan status gizi pada anak baduta ASI eksklusif dan non ASI eksklusif dengan nilai $p$ adalah 0,009 . Hasil tersebut sejalan dengan penelitian sebelumnya yang menyatakan bahwa terdapat perbedaan yang signifikan status gizi bayi yang diberi ASI eksklusif dan susu formula, dimana anak bayi dengan usia 611 bulan yang diberi susu formula mengalami status gizi kurang dan status gizi lebih yang lebih tinggi dibandingkan dengan kelompok anak bayi yang diberi ASI eksklusif ${ }^{13}$. Pemberian ASI eksklusif kepada bayi akan membantunya untuk mencapai pertumbuhan dan perkembangan sesuai dengan usianya dengan tepat. Salah satu capaiannya yaitu status gizi anak tetap dalam keadaan status gizi baik ketika bertambahnya usia ${ }^{21}$. Penambahan asupan makanan anak selain ASI akan diberikan saat anak berusia 6 bulan sebagai pendamping ASI. Pada saat anak berusia diatas 6 bulan, pemberian ASI saja tentu tidak dapat memenuhi seluruh kebutuhan gizinya sehingga diperlukan MPASI yang sesuai dengan usianya ${ }^{22}$. Kandungan zat gizi dalam ASI yang membantu mengoptimalkan masa tumbuh kembang ialah 
laktosa. Laktosa dalam tubuh akan mengalami hidrolisa menjadi glukosa dan galaktosa terlebih dahulu sebelum absorbsi berlangsung. Proses hidrolisa ini dibantu oleh enzim laktase yang terdapat pada brush border mukosa usus halus. Adanya enzim laktase dalam jumlah yang cukup akan membantu meningkatkan absorpsi kalsium pada permukaan saluran pencernaan. Kalsium merupakan zat gizi yang penting dalam pertumbuhan dan mineralisasi tulang anak ${ }^{23}$. Berdasarkan hasil tabulasi silang pada tabel 3 menunjukkan bahwa, kejadian penyakit infeksi pada kedua kelompok yakni 6 anak baduta ASI eksklusif (27,3\%) dan 18 anak baduta non ASI eksklusif (81,8\%). Sedangkan pada kedua kelompok kejadian tidak sakit infeksi yakni 16 anak baduta ASI eksklusif (72,7\%) dan 4 anak baduta (18,2\%).

Berdasarkan uji statistik didapatkan hasil bahwa terdapat perbedaan yang siginifikan kejadian penyakit infeksi pada anak baduta ASI eksklusif dan non ASI eksklusif dengan nilai $p$ adalah 0,001 . Hasil tersebut sejalan dengan penelitian sebelumnya yang menyatakan bahwa terdapat perbedaan signifikan status infeksi pada kedua kelompok 13. Penelitian yang lain menyebutkan bahwa bayi yang tidak diberikan ASI eksklusif terdapat hubungan dengan kejadian ISPA, dimana bayi yang tidak diberikan ASI eksklusif memiliki risiko 4,96 lebih besar mengalami kejadian ISPA dibandingan bayi yang diberi ASI eksklusif $^{24}$. Kejadian penyakit diare juga menunjukkan perbedaan yang signifikan pada bayi yang diberi ASI eksklusif dan bayi yang diberi susu formula ${ }^{9}$. ASI eksklusif mengandung banyak zat antibodi yang khusus untuk kekebalan tubuh bayi. Immunoglobulin A merupakan salah satu jenis zat antibodi yang cukup dikenal dalam ASI, ia bertugas untuk membuat lapisan dalam mukosa usus untuk menjadi barrier yang guna mencegah bakteri patologis masuk ${ }^{25}$.

Kejadian penyakit infeksi pada anak akan berpengaruh pada status gizi anak. Ketika anak mengalami sakit akan muncul gejala klinis penurunan nafsu makan yang memungkinkan asupan makanan anak akan berkurang. Apabila keadaan ini terus terjadi dan disertai oleh muntah dan diare maka kemungkinan hilangnya zat gizi serta cairan pada anak anak semakin besar. Kondisi ini jika terus berlanjut akan berdampak pada perubahan status gizi anak yang semula baik menjadi status gizi kurang bahka gizi buruk ${ }^{4}$. Kejadian penyakit infeksi pada anak baduta erat kaitanya dengan pola asuh, higiene sanitasi, pola pemberian makan anak, dan pelayanan kesehatan dasar. Higiene sanitasi yang dimaksudkan tidak hanya pada diri anak namun juga pada lingkungan tempat tinggal dan ibu/pengasuh yang menyiapkan makan anak. Pola pemberian makan anak harus disesuaikan dengan usia anak supaya tidak menimbulkan masalah kesehatan.

\section{KESIMPULAN}

Terdapat perbedaan pada status gizi dan kejadian penyakit infeksi antara anak baduta ASI eksklusif dan non ASI eksklusif. Ibu yang memiliki bayi diharapkan dapat memberikan asupan makanan yang terbaik untuk anaknya yaitu ASI eksklusif sampai usia enam bulan dan pemberian MPASI yang tepat mulai dari usia enam bulan, serta diharapkan selalu menjaga higieni dan sanitasi lingkungan tempat tinggal dan diri sendiri guna mencegah terjadinya kontaminasi dengan makanan yang dikonsumsi oleh anak.

Penelitian ini memiliki keunggulan yaitu responden anak dalam penelitian ini berusia 12-24 bulan, dimana dari beberapa penelitian yang ada responden penelitian berusia bayi 6-11 bulan. Penelitian ini juga memiliki kekurangan sehingga diperlukan penelitian lebih lanjut terkait dengan status gizi dan kejadian penyakit infeksi pada anak baduta ASI eksklusif dengan menggunakan indikator status gizi TB/U atau BB/TB, karena indikator tersebut akan lebih menggambarkan status gizi masa lampau. Peneliti tidak menggunakan indikator tersebut karena indikator BB/U dapat digunakan untuk melihat status gizi masa sekarang atau masa lampau dan sensitif terhadap perubahan kecil yang dimungkinkan disebabkan oleh kejadian penyakit infeksi dalam satu bulan terakhir.

\section{ACKNOWLEDGMENT}

Terima kasih penulis berikan kepada: Badan Kesatuan Bangsa dan Politik Provinsi 
Jawa Timur, Badan Kesatuan Bangsa dan Politik Kabupaten Sidoarjo, Dinas Kesehatan Kabupaten Sidoarjo, dan Puskesmas Tanggulangin yang telah memberikan izin untuk terlaksananya penelitian ini. Dosen pembimbing atas bimbingan dan pengajaran yang telah diberikan kepada penulis. Para ibu anak baduta yang telah bersedia menjadi responden penelitian.

\section{REFERENSI}

1. Adriani M, Wirjatmadi B. Pengantar Gizi Masyarakat. Jakarta: Kencana; 2012.

2. Dinas Kesehatan Provinsi Jawa Timur. Profil Kesehatan Provinsi Jawa Timur. 2015. Available from http://www.depkes.go.id/resources/dow nload/profil/PROFIL_KES_PROVINSI_2015 115_Jatim_2015.pdf. Diakses pada 9 Oktober 2017.

3. Dinas Kesehatan Kabupaten Sidoarjo. Profil Kesehatan Kabupaten Sidoarjo. 2016. Available from http://dinkes.sidoarjokab.go.id/profilkesehatan-kabupaten-sidoarjo-tahun2015/. Diakses pada 9 Oktober 2017

4. Aziezah, N. Perbedaan Tingkat Konsumsi dan Status Gizi Antara Bayi dengan Pemberian ASI Eksklusif dan Non ASI Eksklusif. Skripsi. Universitas Airlangga; 2011.

5. Susetyowati. Gizi Bayi dan Balita dalam IImu Gizi: Teori dan Aplikasi.Hardiansyah \& Supariasa (editor). Jakarta: EGC; 2016.

6. Marimbi H. Tumbuh Kembang, Status Gizi, dan Imunisasi Dasar Pada Balita. Yogyakarta: Nuha Medika; 2010

7. Kementrian Kesehatan RI. Pedoman Penyelenggaraan Pekan ASI Sedunia Tahun 2017. 2017. Available from http://www.depkes.go.id/resources/dow nload/info-

terkini/Pedoman_Penyelenggaraan_Peka n_ASI_Sedunia_PAS.pdf. Diakses pada 9 Oktober 2017

8. Kementrian Kesehatan RI. Situasi dan Analisis ASI Eksklusif. 2014. Available from

http://www.depkes.go.id/resources/dow nload/pusdatin/infodatin/infodatinasi.pdf. Diakses pada 9 Oktober 2017
9. Rahmitasari $P$, Ichsan B, Ermawati S. Perbedaan Frekuensi Diare Antara Bayi yang Diberi ASI Eksklusif dengan Bayi yang Diberi Susu Formula Pada rentang Usia 2-4 Bulan di Wilayah Kerja Puskesmas Klaten Tengah. Biomedika 2010;4(2). Available from http://download.portalgaruda.org/article .php?article $=354551 \&$ val $=8128 \&$ title $=P E$ RBEDAAN\%2OFREKUENSI\%2ODIARE\%20A NTARA\%20BAYI\%2OYANG\%20DIBERI\%20 ASI\%20EKSKLUSIF\%20DENGAN\%20BAYI\% 20YANG\%20DIBERI\%20SUSU\%2OFORMUL A\%2OPADA\%2ORENTANG\%2OUSIA\%202\%204\%20BULAN\%20DI\%2OWILAYAH\%20 KERJA\%2OPUSKESMAS\%20KLATEN\%20TE NGAH. Diakses pada 9 Oktober 2017.

10. Kementrian Kesehatan RI. Profil Kesehatan Indonesia Tahun 2015. 2016. Available from http://www.depkes.go.id/resources/dow nload/pusdatin/profil-kesehatanindonesia/profil-kesehatan-Indonesia2015.pdf. Diakses pada 9 Oktober 2017.

11. Juliastuti R. Hubungan Tingkat Pengetahuan, Status Pekerjaan Ibu, dan Pelaksanaan Inisiasi Menyusu Dini dengan Pemberian ASI Eksklusif. Tesis. Universitas Sebelas Maret; 2011.

12. Aziezah N, Adriani M. Perbedaan Tingkat Konsumsi dan Status Gizi Antara Bayi dengan Pemberian ASI Eksklusif dan Non ASI Eksklusif. Media Gizi Indonesia 2013;9(1):78-83.

13. Aminah TC, Rahmawati LS, Sulistiyani. Perbedaan Status Gizi dan Status Infeksi Bayi (6-11 Bulan) yang Diberi ASI Eksklusif dengan yang Diberi Susu Formula (Studi di Wilayah Kerja Puskesmas Arjasa Kabupaten Jember). E-journal Pustaka Kesehatan 2014;2(2):293-299. Available from

http://download.portalgaruda.org/article . php?article $=376085 \&$ val $=5039 \&$ title $=$ Per bedaanStatusGizidanStatusInfeksiBayi(611Bulan)yangDiberiASIEksklusifdenganya ngDiberiSusuFormula(StudidiWilayahKerj aPuskesmasArjasaKabupatenJember)[The DifferencesofNutritionalStatusandInfectio nStatusbeetwenExclusiveB. Diakses pada 9 Oktober 2017. 
14. Setyarini A, Mexitalia M, Margawati A. Pengaruh Pemberian ASI Eksklusif dan Non ASI Eksklusif terhadap Mental Emosional Anak Usia 3-4 Tahun. Jurnal Gizi Indonesia 2015;4(1):16-21. Available from

http://ejournal.undip.ac.id/index.php/jgi/ article/view/12323/9329. Diakses pada 9 Oktober 2017

15. Unicef. Paket Konseling Pemberian Makan Bayi dan Anak. 2016. Available from

https://www.google.com/url?sa=t\&rct=j

$\& q=\&$ esrc $=s \&$ source $=w e b \& c d=4 \& v e d=0 a$ hUKEwjY-

pyE8uPWAhUGkpQKHbiOAlgQFgg-

MAM\&url=https\%3A\%2F\%2Fwww.medb

ox.org\%2Fpaket-konseling-pemberian-

makan-bayi-dan-

anak\%2Fdownload.pdf\&usg=AOvVaw2FK

etllq_LDOJnP8me_rSU. Diakses pada 9 Oktober 2017

16. Riksani R. Keajaiban ASI. Jakarta: Dunia Sehat; 2012.

17. Kusumayanti N. Faktor Determinan Pemberian ASI Eksklusif di Kecamatan Kademangan Kabupaten Blitar. Skripsi. Universitas Airlangga; 2017.

18. Kurniawan B. Determinan Keberhasilan Air Susu Ibu Eksklusif. Jurnal Kedokteran Brawijaya 2013;27(4):236-240. Available from

https://www.google.com/url?sa=t\&rct=j $\& q=\&$ esrc $=s \&$ source $=w e b \& c d=2 \&$ ved $=0 a$ hUKEwj34u7s8uPWAhWMEpQKHaxJDG8 QFggvMAE\&url=http\%3A\%2F\%2Fjkb.ub.a c.id\%2Findex.php\%2Fjkb\%2Farticle\%2Fdo wnload\%2F365\%2F346\&usg=AOvVaw0b wBInZlelkf14wl7pimXg. Diakses pada 9 Oktober 2017

19. Kusuma KE. Faktor Risiko Kejadian Stunting pada Anak Usia 2-3 Tahun (Studi di Kecamatan Semarang Timur). Skripsi. Universitas Diponegoro; 2013.

20. Febriyanti R, Dwi E. Analisis Faktor-Faktor yang Mempengaruhi Pemberian ASI Eksklusif di Desa Gilang Taman Sidoarjo. Jurnal Keperawatan 2014: pp. 7-10. Available from http://www.stikeshangtuahsby.ac.id/v1/?mod=jurnal_detail\&title=A nalisis\%20Faktor\%20Yang\%20Mempenga
ruhi\%20Pemberian\%20ASI\%20Eksklusif\% 20Di\%20Desa\%20Gilang\%20Taman\%20Si doarjo\&id=106. Diakses pada 9 Oktober 2017

21. Roesli U. Inisiasi Menyusui Dini Plus ASI Eksklusif. Jakarta: Pustaka Bunda; 2008.

22. Dintansari EO, Anasari T, Fridayanti W. Studi Komparatif Penambahan Berat Badan Bayi Umur 0-6 bulan yang Diberi MP-ASI dan Tanpa Diberi MP-ASI. Jurnal Ilmiah Kebidanan 2010;1(1):98-107. Available from http://download.portalgaruda.org/article .php?article $=200721 \&$ val $=6633 \&$ title $=S T$ UDI KOMPARATIF PENAMBAHAN BERAT BADAN BAYI UMUR 0-6 BULAN YANG DIBERI MP-ASI DAN TANPA DIBERI MPASI. Diakses pada 9 Oktober 2017

23. Soetjiningsih. ASI: Petunjuk Untuk Tenaga Kesehatan. Jakarta: EGC; 1997. Available from

https://books.google.co.id/books?id=S5jF 4XXpwP4C\&pg=PR2\&lpg=PR2\&dq=petunj uk+untuk+tenaga+kesehatan+ASI+asalah \&source=bl\&ots=xkwor2916p\&sig=fNP9O t9_i7mzGpoBtaCDr6Pf_50\&hl=id\&sa=X\&r edir_esc $=y \# v=$ onepage $\& q=$ petunjuk $\% 20 u$ ntuk\%20tenaga\%20kesehatan\%20ASI\%20 asalah\&f=false. Diakses pada 9 Oktober 2017

24. Widarini NP, Sumasari NL. Hubungan Pemberian ASI Eksklusif dengan Kejadian ISPA pada Bayi. Jurnal IImu Gizi (JIG) 2010;1(1):28-41. Available from http://poltekkesdenpasar.ac.id/files/JIG/V1N1/widarini.p df. Diakses pada 9 Oktober 2017.

25. Rahman A, Nur AF. Hubungan Pemberian ASI Eksklusif dengan Kejadian Penyakit Infeksi Saluran Pernafasan Akut Pada Anak Balita di Wilayah Kerja Puskesmas Managaisaki. Jurnal Kesehatan Tadulako 2015;1(1):39-48. Available from https://www.google.com/url?sa=t\&rct=j $\& q=\&$ esrc $=s \&$ source $=$ web $\& c d=1 \& c a d=r j a$ \&uact $=8 \&$ ved $=0$ ahUKEwj9u8LcoOXWAhV ENJQKHZCyCZ4QFggmMAA\&url=http\%3A \%2F\%2Fjurnal.untad.ac.id\%2Fjurnal\%2Fin dex.php\%2FHealthyTadulako\%2Farticle\% 2Fdownload\%2F5732\%2F4498\&usg=AOv Vaw2m7hdkoEEiNIBQ5hSbFcjy. Diakses pada 9 Oktober 2017 